\title{
Analisis Auditor Internal Sebagai Whistleblower Internal Pada Instansi Sektor Publik Dan Swasta
}

\author{
Dina Dwi Oktavia Rini \\ Universitas Muhammadiyah Sidoarjo \\ dinador@umsida.ac.id
}

\author{
Fityan Izza Noor Abidin \\ Universitas Muhammadiyah Sidoarjo \\ fityan_umsida@yahoo.co.id
}

\author{
Noor Fatimah Mediawati \\ Universitas Muhammadiyah Sidoarjo \\ fatimah@umsida.ac.id
}

Corresponding Author : Dina Dwi Oktavia Rini

Submitted: 7 Januari 2020

Accepted: 1 Agustus 2020

Published: 1 Agustus 2020

\begin{abstract}
ABSTRAK
Tujuan penelitian ini (1) untuk menganalisis peran auditor internal pada organisasi sektor publik, (2) untuk menganalisis peran auditor internal pada organisasi sektor swasta, (3) untuk menganalisis peran auditor sebagai whistleblower internal pada organisasi sektor publik, (4) untuk menganalisis peran auditor sebagai whistleblower internal pada organisasi sektor swasta.Penelitian ini akan menggunakan metode kualitatif, dengan menyasar manajer middle dan lower level dari organisasi sektor swasta, meliputi: supervisor, kepala bagian, manajer, dan dari pemerintah daerah yaitu pejabat setingkat kepala, kepala bagian/bidang/subdinas dan kepala subbagian/subbidang/ seksi dari badan, dinas dan kantor pada Pemerintah Daerah Kabupaten Sidoarjo. Hasil dari penelitian ini adalah auditor internal memiliki peranan yang cukup berpengaruh dalam proses pengambilan suatu keputusan yang akan dilakukan oleh manajemen puncak suatu organisasi. Hal ini karena auditor internal bersifat independen dan informasi yang disampaikan oleh auditor internal sebagai whistleblower internal dapat dijadikan indikator dalam pengambilan keputusan (decision making)
\end{abstract}

Kata Kunci: Internal Auditor, WhistleblowerInternal

\section{ABSTRACT}

The purpose of this study (1) to analyze the role of internal auditors in public sector organizations, (2) to analyze the role of internal auditors in private sector organizations, (3) to analyze the role of auditors as internal whistleblowers in public sector organizations, (4) to analyze the role auditors as internal whistleblowers in private sector organizations.This study will use qualitative methods, targeting middle and lower level 
managers of private sector organizations, including: supervisors, section heads, managers, and from local governments, namely officials at the head level, section / division / subdinas heads and subdivision / subdivision / section heads from agencies, offices and offices in the Sidoarjo Regency Government.The expected results in this study are that internal auditors can be a whistleblower for organizations both in the public sector and the private sector. The results of this study are internal auditors have a significant role in the decision making process that will be carried out by the top management of an organization. This is because the internal auditor is independent and the information conveyed by the internal auditor as an internal whistleblower can be used as an indicator in decision making.

Keywords: Internal Auditor, Internal Whistleblower

\section{PENDAHULUAN}

Era disrupsi saat ini semakin besar dikarenakansemakin berkembangnya teknologi dan bisnis model. Oleh karenanya tantangan profesi auditor internal akan semakin besar pula. Auditor internal diharapkan meninggalkan paradigma lama yang hanya mencari kesalahan-kesalahan di masa lalu.

Salah satu fungsi manajemen adalah controlling, maka manajemen suatu organisasi baik sektor publik maupun pemerintah memerlukan peran auditor internal yang dapat mendukung keberjalanan fungsinya dalam menjamin organisasi berjalan sesuai dengan perencanaan dan mengarah pada suatu tujuan.

Dalam rangka mewujudkan tata kelola suatu organisasi yang baik, peran auditor internal yang independen sangatlah penting sebagai suatu bagian komponen monitoring struktur pengendalian internal dari suatu organisasi dan audit internal merupakan kegiatan pemastian dan konsultasi yang independen dan objektif yang dirancang untuk menambah nilai dan meningkatkan operasi organisasi. Dalam lingkungan pemerintah, fungsi monitoring struktur pengendalian internal dilakukan oleh pengendalian intern, penilai efektivitas struktur pengendalian intern, dan penilai kualitas kerja. Sukrisno Agoes (2013) dalam bukunya mengatakan bahwa Internal Audit (pemeriksaan intern) adalah pemeriksaan yang dilakukan oleh bagian internal audit suatu perusahaan, terhadap laporan keuangan dan catatan akuntansi perusahaan maupun ketaatan terhadap kebijakan manajemen puncak yang telah ditentukan dan ketaatan terhadap peraturan pemerintah dan ketentuan-ketentuan dari ikatan profesi yang berlaku.

Audit terhadap institusi sektor publik menjadi fokus perhatian karena dinilai instansi pemerintah tidak terbuka terhadap masyarakat mengenai kondisi keuangan sebenarnya, dan baru disadari bahwa lembaga eksekutif hanya sebagai pihak yang mengelola uang negara yang merupakan uang rakyat, sehingga perlu untuk dipertanggungjawabkan dan perlu diperiksa kewajarannya. Dan instansi sektor publik rawan akan terjadinya penyalahgunaan, sehingga dibutuhkan aturan yang ketat dan audit yang independen. Sehingga dalam pelaksanaannya, diharapkan audit internal dituntut memiliki sikap profesionalisme. Audit internal juga merupakan katalis untuk meningkatkan efektivitas organisasi dan efisiensi dengan memberikan wawasan dan rekomendasi berdasarkan analisis dan penilaian data dan proses pebisnis. 
Auditor internal dengan sikap profesionalismenya dapat melakukan whistleblowing untuk mengungkap segala bentuk kecurangan yang terjadi dalam suatu instansi. Peristiwa whistleblowing tidak menutup kemungkinan terjadi dalam lingkup interaksi dalam organisasi. Terlebih jika pengawasan dalam organisasi tersebut tidak sehat. Tujuan whistleblowing adalah untuk memperbaiki atau mencegah suatu tindakan yang merugikan. Menurut Brandon (2013), whistleblowing merupakan tindakan yang dilakukan oleh seseorang atau beberapa orang karyawan untuk membocorkan kecurangan baik yang dilakukan oleh perusahaan atau atasannya kepada pihak lain. Kebanyakan penelitian menunjukkan bahwa karyawan yang lebih tua dan lebih berpengalaman memiliki kecenderungan yang lebih tinggi untuk melakukan whistleblowing. Hal itu dikarenakan semakin berpengalaman seseorang maka makin berkomitmenlah mereka kepada organisasi tempat mereka bekerja (Sagara, 2013). Maka niat untuk melaporkan akan muncul ketika ditemukan adanya kecurangan yang membahayakan keberadaan organisasi mereka. Pada kenyataannya whistleblower acapkali mendapatkan tekanan dan berbagai intimidasi, bahkan ancaman diberhentikannya dari jabatan.

Beberapa penelitian telah dilakukan untuk melihat peran auditor internal. Dalam penelitian Dina (2016) tentang Pengaruh Perceived Environmental Uncertainty dalam Pelaksanaan Audit Internal Terhadap Intensi Whistleblowing sebagai Upaya Pencapaian GCG di Sidoarjo dengan hasil: $P E U$ yang tidak berpengaruh langsung terhadap pelaksanaan audit internal, tapi lebih berpengaruh terhadap intensi whistleblowing.Pelaksanaan audit internal menjadi media yang sangat efektif dalam pencapaian $G C G$. Tentunya pelaksanaan audit tersebut bergantung pada program audit yang ditetapkan, sehingga secara otomatis penetapan tersebut membutuhkan informasi, dimana informasi yang diperoleh medapat peran dari $P E U$. Dalam penelitian Mulfag (2017) tentang Intensi Melakukan Whistleblowing pada Internal Auditor Pemerintah dengan hasil auditor perempuan lebih cenderung memiliki intensi melakukan whistleblowing dibandingkan auditor laki-laki, dan auditor junior lebih cenderung memiliki intensi melakukan Whistleblowing dibandingkan auditor senior. Perbedaannya dengan penelitian saat ini adalah apakah ada perbedaan peran auditor internal sebagai whistleblower internal pada instansi sektor publik dan sektor swasta.

\section{TINJAUAN LITERATUR \\ 2.1. Auditor Internal}

Secara umum, audit internal merupakan penilaian atas suatu keyakinan yang independen, obyektif, dan aktivitas konsultasi yang dirancang untuk memberikan nilai tambah dan meningkatkan operasional suatu organisasi.

Berbeda dengan pemeriksaan yang dilakukan oleh KAP, yang tujuannya adalah memberikan pendapat atas kewajaran laporan keuangan yang disusun manajemen, maka tujuan pemeriksaan yang dilakukan oleh auditor internal adalah untuk membantu jajaran pimpinan organisasi (manajemen) dalam melaksanakan tanggung jawabnya dengan memberikan analisa, penilaian saran, dan komentar mengenai kegiatan yang diperiksanya. (Agoes, 2013:205)

\subsection{Peran dan Fungsi Auditor Internal}


Auditor internal memiliki peranan yang penting dalam semua hal yang berkaitan dengan pengelolaan perusahaan dan resiko-resiko terkait dalam menjalankan usaha (Sawyer, 2005).

Menurut Sawyer's (2005:32) peranan auditor internal dalam perusahaan adalah sebagai berikut:

1. Mengawasi kegiatan-kegiatan yang tidak dapat diawasi sendiri oleh manajeman puncak.

2. Mengidentifikasi dan meminimalkan resiko.

3. Mevalidasi laporan ke manajer senior.

4. Membantu manajemen pada bidangbidangteknis.

5. Membantu proses pengambilan keputusan.

6. Menganalisa masa depan, bukan hanya untuk masa lalu.

7. Membantu manajer untuk mengelola perusahaan.

Fungsi audit internal secara terperinci dan relatif lengkap menunjukkan bahwa aktivitas audit internal harus diterapkan secara menyeluruh terhadap seluruh aktivitas perusahaan, sehingga tidak hanya terbatas pada audit atas catatan-catatan akuntansi.

$$
\text { Dalam menjalankan }
$$

fungsinya tersebut auditor internal melaksanakan kegiatan-kegiatan berikut ini:

1. Pemeriksaan dan penilaian terhadap efektivitas struktur pengendalian intern dan mendorong penggunaan struktur pengendalian intern yang efektif dengan biaya yang minimum.

2. Menentukan sampai seberapa jauh pelaksanaan kebijakan manajemen puncak dipatuhi.

3. Menentukan sampai seberapa jauh kekayaan perusahaan dipertanggungjawabkan dan dilindungi dari segala macam kerugian.

4. Menentukan keandalan informasi yang dihasilkan oleh berbagai bagian dalam perusahaan.

5. Memberikan rekomendasi perbaikan kegiatan-kegiatan perusahaan.

\subsection{Jenis-jenis Whistleblowing}

Menurut Hertanto (2009:12)

dalam Libramawan (2014)

whistleblowing dikategorikan menjadi dua jenis:

a. Whistleblowing internal

b. Whistleblowing eksternal

Dari kedua jenis whistleblowing

di atas, dapat disimpulkan bahwa whistleblowing internal terjadi ketika seorang karyawan mengetahui kecurangan yang dilakukan karyawan kemudian melaporkan kecurangan tersebut kepada atasannya. Sedangkan Whistleblowing eksternal terjadi ketika seorang karyawan mengetahui kecurangan yang dilakukan oleh perusahaan lalu membocorkannya kepada masyarakat karena kecurangan itu akan merugikan masyarakat.

Jadi, whistleblowing external maupun whistleblowing internal dapat disampaikan kepada pihak manajemen perusahaan. Apabila tidak mendapat tanggapan baik dari dalam perusahaan, maka pelaporan bisa dilakukan kepada pihak luar perusahaan dengan catatan mempunyai bukti yang kuat. Karyawan tersebut melaporkan tindakan perusahaan kepada Lembaga Swadaya Masyarakat (LSM) atau media masa karena laporannya tidak mendapat tanggapan dari manajemen yang dianggap tidak loyal terhadap perusahaan.

\subsection{Whistleblower Internal}

Karyawan yang melaporkan kemungkinan kecurangan, pelanggaran 
serta aktivitas yang tidak jujur atau kecurangan lain yang dilakukan oleh orang lain di tempat kerja dikenal dengan istilah whistleblower. Whistleblowerinter nal dapat dimanfaatkan sebagai sumber informasi yang mungkin luput dari pengawasan auditor guna meningkatkan kualitas audit internal.

Ada beberapa hal yang harus dijamin oleh auditor internal dalam menanggapi informasi dari whistleblowers. Pertama, auditor internal selaku badan yang independen harus mampu memberikan nasihat, apakah isu yang dilaporkan dapat diselesaikan secara internal atau harus diungkapkan ke publik (external disclosure) dan harus ada aturan yang jelas untuk menangani masalah ini. Kedua, auditor internal harus sedapat mungkin menjaga kerahasiaan identitas sang pelapor. Ketiga, isu tersebut harus diproses dengan cara yang sama seperti temuan audit lainnya dan dilaksanakan secara profesional. Terakhir, bila pihak internal seperti pihak manajemen dan petinggi perusahaan lainnya tidak mengindahkan laporan tersebut, maka isu tersebut dapat diungkap ke publik sebagaimana diatur dalam undangundang. Selain itu, auditor internal harus mampu mempertahankan independensinya, jangan sampai mencampurkan kepentingan perusahaan dengan pemeriksaan.
Penanganan yang benar oleh audit internal dalam menanggapi laporan dari whistleblower harus dapat dimanfaatkan secara efektif dan dipandang dari sisi positifnya. Prosedur yang benar tersebut antara lain auditor internal harus dapat menjaga independensinya, bijaksana dalam menangani laporan dari whistleblower, dan dapat menjamin kerahasiaan indentitas whistleblower. Agar

whistleblower dapat melaporkan suatu pelanggaran atau tindak pidana, tentu diperlukan saluran komunikasi langsung atau khusus kepada pemimpin eksekutif atau Dewan Komisaris. Misalnya, melalui nomor telepon tertentu, hotline khusus, email, atau saluran komunikasi yang lain. Saluran komunikasi itu tentu juga perlu disosialisasikan kepada pekerja sehingga sistem pelaporan dapat diketahui dan berjalan lebih efektif (Semendawai, 2011:21).

\section{METODE PENELITIAN Obyek Penelitian}

Penelitian ini dilakukan pada organisasi sektor swasta dan organisasi sektor publik di Kabupaten Sidoarjo. Partisipan yang ditetapkan merupakan manajer middle and lower level dari organisasi sektor swasta, meliputi: supervisor, kepala bagian, manajer. 


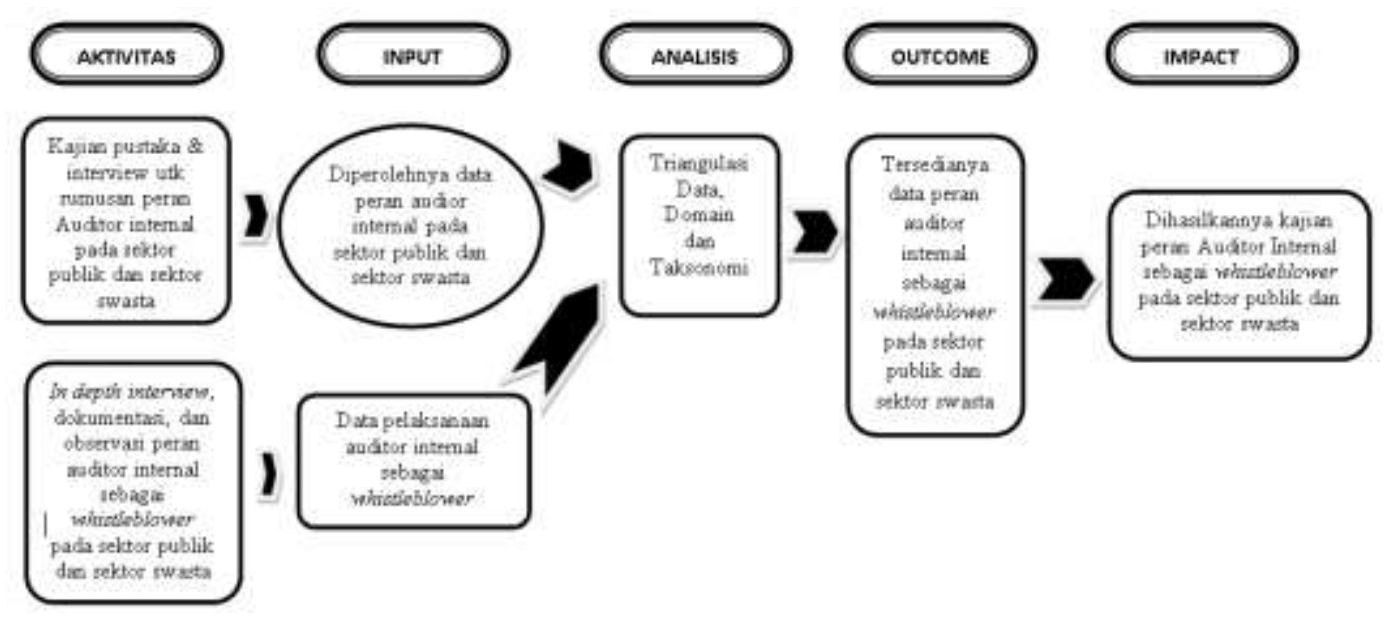

\section{HASIL DAN PEMBAHASAN}

4.1. Auditor Internal pada Organisasi Sektor Swasta dengan Organisasi Sektor Publik

Pelaksanaan audit dalam organisasi sektor publik berbeda dengan pelaksanaan audit pada organisasi sektor swasta, yaitu perbedaan latar belakang institusional dan hukum. Audit pada sektor publik mempunyai prosedur dan tanggung jawab berbeda serta peran yang lebih luas daripada sektor swasta. Untuk memaknai pemahaman dan peran auditor internal pada saat in depth interview, peneliti menanyakan pemahaman dan peran auditor internal pada Supervisor Auditor Internal dan Koordinator Asisten Manajer dari perusahaan swasta, Ka.Sie. Piutang Negara dari organisasi pemerintah, auditor internal dari organisasi sektor publik (dalam penelitian ini adalah bank dan distributor). Pendapat oleh organisasi swasta, yang pertama disampaikan oleh Ibu DN terkait dengan pemahaman dan peran auditor internal pada organisasi swasta. Berikut komentarnya:

"Auditor internal merupakan pelaksana yang bersifat independen yang dibentuk oleh suatu organisasi untuk menguji dan mengevaluasi berbagai kegiatan di dalam organisasi tersebut. Sedangkan fungsi auditor internal yaitu mengevaluasi atau menguji aktivitas perusahaan dalam lingkup manajemen risiko, proses pengamanan aktiva serta mempertahankan kepatuhan atas kebijakan yang telah ditetapkan." (petikan komentar Ibu DN saat interview 09/04/2020)

Pendapat yang kedua disampaikan oleh Bapak BSJ, berikut komentarnya:

"Auditor internal adalah orang yang pekerjaannya melakukan pemeriksaan terhadap pelaksanaan pekerjaan di suatu perusahaan apakah sesuai dengan SOP yang ditentukan perusahaan tersebut ataukah ada penyimpangan di dalamnya dan membuat laporan atas hasil pemeriksaannya tersebut. Sedangkan fungsi auditor internal adalah:

a. Memastikan SOP perusahaan berjalan sebagaimana mestinya di semua lini departemen

b. Memeriksa apakah ada penyimpangan dalam pelaksanaan pekerjaan di setiap lini departemen

c. Auditor internal berfokus pada manajemen risiko/mengurangi resiko tindakan penipuan oleh internal perusahaan, proses pengamanan mempertahankan kepatuhan (compliance) terhadap peraturan." 
(petikan komentar Bapak BSJ saat interview 11/04/2020)

Senada dengan pendapat yang disampaikan oleh informan dari organisasi sektor publik, Ibu IO (perbankan) dan Bapak AF (distributor) . Berikut komentarnya:

"Auditor internal yaitu suatu fungsi penilaian independen yang dibuat dalam suatu organisasi dengan tujuan menguji dan mengevaluasi berbagai kegiatan yang dilaksanakan organisasi. Fungsinya adalah membantu semua tingkatan manajemen dalam mengamankan kegiatan operasional perusahaan" (petikan komentar Ibu IO saat interview 28/03/2020)

"Internal auditor merupakan auditor yang bekerja di suatu perusahaan dan bertugas untuk mengetahui apakah prosedur serta kebijakan yang telah ditetapkan oleh manajemen telah dipatuhi oleh seluruh karyawan, termasuk menentukan keandalan informasi yang telah dihasilkan oleh bagian-bagian di suatu perusahaan. Fungsinya untuk menentukan: (1) resiko yang dihadapi perusahaan telah diidentifikasi dan diminimalisasi; (2) peraturan eksternal serta prosedur internal telah diikuti oleh seluruh karyawan; (3) sumber daya digunakan secara efektif dan efisien; (4) informasi keuangan dan kegiatan operasional telah akurat; (5) tujuan perusahaan telah dicapai secara efektif dan efisien." (petikan komentar Bapak AF saat interview 06/04/2020)

Pendapat lainnya disampaikan oleh Bapak AP dari instansi pemerintah sebagai berikut:

"Auditor internal adalah pengawas dan pemeriksa di internal instansi, yang mempunyai fungsi untuk memastikan tugas dan fungsi instansi telah dilaksanakan sesuai dengan ketentuan yang berlaku" (petikan komentar Bapak AP saat interview 27/03/2020)

Dengan demikian berdasarkan hasil penelitian dengan in depth interview, dan dokumentasi yang didukung oleh triangulasi sumber menyatakan bahwa auditor internal merupakan karyawan dari suatu perusahaan/instansi yang mempunyai sifat independen, bertanggung jawab terhadap manajemen puncak yang bertugas menganalisa dan mengevaluasi kegiatan suatu organisasi apakah telah sesuai dengan prosedur dan tujuan organisasi. Auditor internal tersebut mempunyai fungsi untuk memastikan kegiatan operasional organisasi telah sesuai dengan peraturan eksternal dan prosedur internal serta mengkomunikasikan penyimpangan yang terjadi dalam organisasi, baik sektor swasta, publik, maupun pemerintah.

Adanya kesamaan persepsi antara para keyinforman dengan teori yang menjadi landasan penelitian ini, sehingga bisa dikatakan bahwa para keyinforman sangat paham tentang definisi dan fungsi auditor internal.

\subsection{Pemahaman Whistleblowing}

Informasi apapun yang terkait dengan aktivitas dan kegiatan suatu organisasi hendaknya mendapatkan evaluasi yang obyektif untuk dapat diberikan suatu rekomendasi yang positif untuk perbaikan-perbaikan manajemen organisasi, demikina juga jika terjadi adanya kemungkinan penyimpangan prosedur dan kecurangan. Informasi tersebut dapat dilakukan oleh karyawan atau pihak luar organisasi, yang kemudian disebut sebagai whistleblowing.

Pendapat yang disampaikan oleh organisasi sektor publik mengenai pemahaman tentang whistleblowing, adalah sebagai berikut: 
1. (petikan komentar Ibu IO saat interview28/03/2020)

"Pihak/orang yang melaporkan suatu tindakan yang dianggap melanggar ketentuan kepada pihak yang berwenang"

2. (petikan komentar Bapak AF saat interview 06/04/2020)

"Pendeteksian terhadap tindakan kecurangan (yang melanggar tindakan hukum maupun peraturanperaturan yang telah ditetapkan"

Sedikit berbeda dengan yang sampaikan oleh Bapak AP dari instansi pemerintah. Berikut adalah komentarnya mengenai whistleblowing:

"Fungsi pengawasan yang berasal dari eksternal maupun internal selain auditor internal."(petikan komentar Bapak AP saat interview 27/03/2020)

Opini yang diberikan oleh praktisi dari instansi swasta adalah sebagai berikut:

"Whistleblowing adalah tindakan yang dilakukan oleh pihak tertentu untuk membocorkan kecurangan yang terjadi di dalam organisasi kepada pihak lain." (petikan komentar dari Ibu DN saat interview 09/04/2020)

"Whistleblowing merupakan pengungkapan bila terjadi penyimpangan/kesalahan yang ditemukan dalam internal audit." (petikan komentar Bapak BSJ saat interview 11/04/2020)

Berdasarkan beberapa komentar tersebut di atas, dapat diketahui bahwa whistleblowing dipahami sebagai pengungkapan penyimpangan dan/atau kecurangan kepada pihak yang berwenang, dalam hal ini adalah manajemen puncak. Dimana penyimpangan dan/atau kecurangan tersebut sebagai akibat dari tidak dipatuhinya aturan dan prosedur instansi.

Hasil dari in depth interview pun memberikan gambaran pemahaman keyinforman terhadap whisteblowing yang mendasari persepsi keyinforman dalam perannya sebagai whistleblower internal.

\subsection{Auditor Internal sebagai Whistleblower Internal}

Berdasarkan dari uraian sebelumnya, ada beberapa hal yang dapat dijadikan bahasan lebih lanjut. Seperti komentar dari Bapak AP dari instansi pemerintah berikut ini:

"Auditor internal seharusnya bisa menjadi whistleblower." (petikan komentar dari Bapak AP saat interview 27/03/2020)

Sedangkan pendapat dari instansi swasta, Bapak BSJ dan Ibu DN adalah sebagai berikut:

"Auditor internal dapat menjadi whistleblower internal untuk mengungkapkan semua kecurangan yang terjadi di dalam organisasi kepada pihak eksternal atau pihak di dalam organisasi tersebut." (petikan komentar Ibu DN saat interview 09/04/2020)

"Auditor internal bisa menjadi whistleblower asal dibekali dengan SOP yang jelas dari perusahaan di masingmasing departemen seorang auditor internal akan melakukan pemeriksaan antara SOP dengan pelaksanaan pekerjaan." (petikan komentar Ibu BSJ saat interview 11/04/2020)

Sejalan dengan pendapat dari instansi swasta, informan dari instansi sektor publik memberikan pendapat sebagai berikut:

"Auditor internal bisa menjadi whistleblower, karena merupakan salah satu ruang lingkup pekerjaan seorang auditor adalah memberikan informasi kepada pihak yang berwenang". (petikan komentar Ibu IO saat interview 28/03/2020) 
"Auditor internal bisa menjadi whistleblower". (petikan komentar Ibu IO saat interview 28/03/2020)

Dari pendapat-pendapat tersebut di atas, maka auditor internal dapat menjadi whistleblower internal, baik sektor swasta maupun sektor publik, dan sangat diharapkan dapat memberikan informasi dari masing-masing bagian di organisasi kepada pihak yang berwenang, dalam hal ini adalah manajemen puncak.

\subsection{Peran Auditor Internal sebagai Whistleblower Internal}

Tata kelola organisasi yang baik atau yang dikenal sebagai Good Corporate Governance (GCG) adalah salah satu tujuan dari organisasi, baik sektor swasta maupun sektor publik, merupakan suatu prinsip yang mengarahkan dan mengendalikan perusahaan agar mencapai keseimbangan antara kewenangan perusahaan dalam memberikan pertanggungjawaban kepada para shareholder khususnya, dan stakeholders pada umumnya. oleh Ibu DN:

Komentar pertama diberikan

"Semakin tinggi tingkat profesionalisme seorang internal auditor terhadap pekerjaannya, maka intensi untuk melakukan whistleblowing semain tinggi pula."(petikan komentar Ibu DN saat interview 09/04/2020)

Komentar lain diungkapkan oleh Bapak BSJ:

"Auditor internal mempunyai peran yang cukup besar sebab auditor internal adalah pihak yang netral yang membantu perusahaan untuk memeriksa compliance apakah terjadi penyimpangan di dalamya atau tidak. Besar kecilnya penyimpangan yang ditemukan oleh seorang internal auditor adalah sebagai masukan bagi perusahaan (whistleblower)." (petikan komentar Bapak BSJ saat interview 11/04/2020)

Sedangkan komentar dari instansi pemerintah adalah sebagai berikut:

"Auditor internal instansi dapat melaporkan penyimpangan di instansi tersebut kepada atasan instansi, tanpa harus konfirmasi kepada pimpinan instansi tersebut."(petikan komentar Bapak AP saat interview 27/03/2020)

Komentar berbeda disampaikan oleh Bapak AF sebagai informan dari instansi sektor publik sebagai berikut:

"Peran auditor internal sebagai whistleblower adalah sebatas hasil audit, yaitu memberi opini dan rekomendasi audit dengan bukti audit yang sah." (petikan komentar Bapak AF saat interview 06/04/2020)

Dari uraian pendapat-pendapat di atas, bahwa auditor internal memiliki peranan yang cukup berpengaruh dalam proses pengambilan suatu keputusan yang akan dilakukan oleh manajemen puncak suatu organisasi. Hal ini karena auditor internal bersifat independen berdasarkan data-data obyektif untuk dapat menyampaikan terjadinya suatu penyimpangan atau bahkan terjadinya kecurangan.

\subsection{Informasi Auditor Internal sebagai Whistleblower Internal dalam Pengambilan Keputusan}

Seperti yang telah dibahas pada paragraf-paragraf sebelumnya, bahwa auditor dapat memberikan informasiinformasi mengenai berbagia bentuk penyimpangan bahkan kemungkinan adanya kecurangan sehingga auditor internal sebagai whistleblower internal dapat memberikan rekomendasi untuk perbaikan kepada pihak manajemen puncak.

Ada beberapa pendapat dari para key informan mengenai informasi auditor 
internal sebagai whistleblower internal dalam decision making.

Dari instansi sektor publik, Ibu IO dan Bapak AF memberikan pendapat sebagai berikut:

"Informasi yang disampaikan auditor internal sebagai whistleblower internal adalah cukup efektif karena laporan yang dibuat oleh auditor internal dapat menjadi satu acuan dalam pengambilan keputusan."(petikan komentar Ibu IO saat interview 28/03/2020)

"Informasi audit harus berdasarkan bukti audit dan dasar $5 \mathrm{~W} 1 \mathrm{H}$ (what, who, where, why, when, dan how)yang valid agar tujuan perusahaan tercapai secara efektif dan efisien."(petikan komentar Bapak AF saat interview 06/04/2020)

Pendapat lainnya disampaikan key informas dari instansi pemerintah sebagai berikut:

"Informasi yang disampaikan auditor internal sebagai whistleblower internal adalah bisa menjadi indikator dalam pengambilan keputusan asalkan ada bukti yang menguatkan tanpa ada tendensi." (petikan komentar Bapak AP saat interview 27/03/2020)

Sedangkan key informan dari instansi swasta berpendapat:

"Informasi yang disampaikan oleh auditor internal dapat digunakan sebagai decision making apabila mempunyai bukti-bukti valid yang dapat dipertanggungjawabkan. Bukti tersebut minimal harus ada 5 unsur, yaitu: (1) what: temuan apa yang mengindikasikan pelanggaran menurut auditor; (2) where: dimana lokasi pelanggaran tersebut; (3) when: kapan pelanggaran tersebut terjadi; (4) who: siapa/pihak mana yang melakukan pelanggaran; dan (5) how: bagaimana seoran auditor bisa mengungkapkan pelanggaran tersebut." (petikan komentar Ibu DN saat interview 09/04/2020)

"Informasi whistleblower dari intern auditor adalah sebagai masukan adanya penyimpangan dari SOP yang ditentukan oleh perusahaan nemun dikembalikan lagi ke perusahaan tersebut apakah temuan itu tetap dianggap sebagai pelanggaran/penyimpangan aturan dari perusahaan ataukah sebagai bahan koreksi untuk perusahaan bahwa aturan/SOP yang sudah dibuat tidak bisa diterapkan lagi di saat ini sehingga perlu adanya modifikasi SOP baru."(petikan komentar Bapak BSJ saat interview 11/04/2020)

Berdasarkan berbagai pendapat key informan tersebut di atas, bahwa informasi yang disampaikan oleh auditor internal sebagai whistleblower internal dapat dijadikan indikator dalam pengambilan keputusan (decision making) jika informasi-informasi tersebut didukung oleh bukti-bukti yang valid dan tidak ada pengaruh dari pihakpihak tertentu (tendensi).

\subsection{Yang Diharapkan dari Auditor Internal sebagai Whistleblower Internal}

Ada yang harus peneliti gali berkaitan dengan apa saja sebenarnya yang diharapkan para key informan dari auditor internal agar paham perannya sebagai whistleblower internal.

Pendapat-pendapat tersebut adalah sebagai berikut:

"Membantu perusahaan untuk secara konsisten memastikan tidak ada penyimpangan, melindungi perusahaan dari kerugian dan meminimalisir faktor resiko, sehingga penyimpangan yang ditemukan dapat dideteksi sedini mungkin sehingga membantu perusahaan untuk dapat berkembang lebih baik dan sehat secara internalnya."(petikan 
komentar Bapak BSJ saat interview 11/04/2020)

"Harapannya adalah dengan hasil audit internal kita bisa membuat langkah-langkah dalam menghadapi permasalahan yang ada dan untuk ke depannya bisa memitigasi risiko yang akan dihadapi." (petikan komentar Ibu IO saat interview 28/03/2020)

"Dapat memberikan informasi yang valid, tanpa ada tendensi, dan tanpa ada intervensi dari pihak manapun, akhirnya instansi tersebut dapat melaksanakan tugas, fungsi SOP sesuai ketentuan yang berlaku."(petikan komentar Bapak AP saat interview 27/03/2020)

"Seorang auditor internal dalam melakukan whistleblower internal tidak boleh asal melakukan pelaporan tanpa bukti yang benar-benar valid, sebab tanpa hasil tersebut berpengaruh tidak hanya di dalam organisasi saja tetapi juga berpengaruh terhadap luar organisasi. Apabila dia memberikan informasi yang tidak benar, maka akan berdampak besar tidak hanya di dalam organisasi tetapi juga di dalam organisasi."'(petikan komentar Ibu DN saat interview 09/04/2020)

"Selalu menjunjung tinggi karakteristik dalam praktek kerja karena internal auditor adalah bagian yang independen dan secara struktural dalam perusahaan bertanggung jawab langsung kepada pemilik perusahaan."(petikan komentar Bapak AF saat interview 06/04/2020)

Begitu banyak harapan yang berhasil peneliti gali dari para key informan yang benar-benar menginginkan peran auditor internal sebagai whistleblower internal dapat benar-benar dijalankan tanpa ada kekhawatiran, tendendi, dan intervensi dari pihak manapun.

\section{SIMPULAN}

5.1. Pemahaman atas Pengertian Auditor Internal bagi Organisasi Sektor Publik, Organisasi Sektor Swasta, dan Organisasi Pemerintah

Berdasarkan dari hasil pembahasan melalui wawancara yang telah dilakukan, bahwa auditor internal tidak lain merupakan karyawan dari suatu perusahaan/instansi yang mempunyai sifat independen, bertanggung jawab terhadap manajemen puncak yang bertugas menganalisa dan mengevaluasi kegiatan/pihak dari suatu organisasi apakah telah sesuai dengan prosedur dan tujuan organisasi atau belum. Auditor internal tersebut mempunyai fungsi untuk memastikan kegiatan operasional organisasi telah sesuai dengan peraturan eksternal (regulasi) dan prosedur internal (SOP) dan dapat menganalisa risikorisiko yang mungkin akan terjadi, serta mengkomunikasikan penyimpangan atau kecurangan yang terjadi dalam organisasi, baik sektor swasta, publik, maupun pemerintah.

\subsection{Pemahaman Whistleblowing}

Kesimpulan dalam penelitian ini adalah whistleblowing dipahami sebagai pengungkapan penyimpangan dan/atau kecurangan kepada pihak yang berwenang, dalam hal ini adalah manajemen puncak. Dimana penyimpangan dan/atau kecurangan tersebut sebagai akibat dari tidak dipatuhinya aturan dan prosedur instansi.

\subsection{Auditor internal sebagai Whistleblower Internal}

Auditor internal dapat menjadi whistleblower internal, baik bagi organisasi sektor swasta maupun sektor publik, dan sangat diharapkan dapat memberikan informasi dari masing- 
masing bagian di organisasi kepada pihak yang berwenang, dalam hal ini adalah manajemen puncak.

\subsection{Peran Auditor Internal sebagai Whistleblower Internal}

Auditor internal memiliki peranan yang cukup berpengaruh dalam proses pengambilan suatu keputusan yang akan dilakukan oleh manajemen puncak suatu organisasi. Hal ini karena auditor internal bersifat independen berdasarkan datadata obyektif untuk dapat menyampaikan terjadinya suatu penyimpangan atau bahkan terjadinya kecurangan.

\subsection{Informasi Auditor Internal sebagai Whistleblower Internal dalam Pengambilan Keputusan}

Informasi yang disampaikan oleh auditor internal sebagai whistleblower internal dapat dijadikan indikator dalam pengambilan keputusan (decision making) jika informasi-informasi tersebut didukung oleh bukti-bukti yang valid dan tidak ada pengaruh dari pihakpihak tertentu (tendensi).

\subsection{Yang Diharapkan dari Auditor Internal sebagai Whistleblower Internal}

Banyak harapan dari para key informan yang benar-benar menginginkan peran auditor internal sebagai whistleblower internal dapat benar-benar dijalankan tanpa ada kekhawatiran, tendensi, dan intervensi dari pihak manapun.

\section{UCAPAN TERIMA}

Ucapan terima kasih yang tak terhingga kepada semua pihak yang telah membantu peneliti selama proses penelitian hingga ter-published nya hasil penelitian ini.

\section{DAFTAR PUSTAKA}

(1) Agoes, Sukrisno. 2013. Auditing: Petunjuk Praktis Pemeriksaan
Akuntan oleh Akuntan Publik.

Salemba Empat: Jakarta.

(2) Arief, dan Bambang. 2007. Mekanisme Corporate Governance, Manajemen Laba dan Kinerja Keuangan (Studi Pada Perusahaan Go Public Sektor Manufaktur). Simposium Nasional Akuntansi X.

(3) Brandon. 2013. Whistleblower. http://www.scribd.com/doc/1233185 39/Whistle-Blower. Diakses pada tanggal 5 Juni 2017.

(4) Dzaky C.P., Vicky. 2014. Peran Audit Internal Dalam Upaya Mewujudkan GoodCorporate Governance. Universitas Widyatama.

(5) Fahmi, Irham. 2013. Etika Bisnis: Teori, Kasus, dan Solusi. Bandung: Alfabeta.

(6) G. Kumaat, Valery. 2011. Internal Audit. Erlangga: Jakarta.

(7) Hery. 2010. PotretProfesi Audit Internal Di Perusahaan Swasta dan BUMN Terkemuka. Bandung: Alfabeta.

(8) Komite Nasiional Kebijakan Governance. 2008. Pedoman Sistem Pelaporan-SPP (Whistleblowing System-WBS). Jakarta.

(9) Libramawan, Irvandly Pratana. 2014. Pengaruh Penerapan Whistleblowing System Terhadap Pencegahan Kecurangan (Studi Survey pada PT. Coca Cola Amatil Indonesia SO Bandung). Skripsi. Fakultas Ekonomi Universitas Widyatama. Bandung. 
(10) M. Rizki Putra Mulfag. 2017. "Intensi Melakukan Whistleblowing pada Internal Auditor Pemerintah". Skripsi. Fakultas Ekonomi. Universitas Negeri Padang.

(11) Moloeng, Lexy J. 2007. Metodologi Penelitian Kualitatif. PT. Remaja Rosdakarya Offset. Bandung

(12) Mulyadi, 2008. Auditing, Buku Satu \& Dua. Edisi Keenam. Jakarta: Salemba Empat.

(13) Pickett, KH. Spencer. 2010. The Internal Auditing Handbook. Edisi ke-3. John Wiley \& Sons Ltd.

(14) Questibrilia, Bivisyani. 2019. Pentingnya Whistleblowing Bagi Perusahaan dan cara Penerapannya. https://www.jojonomic.com/blog/whi stle-blowing/. Diakses pada tanggal 5 Juni 2017.

(15) Rahardian, Malik. (2010), “Analisis Perbedaan Komitmen Profesional dan Sosialisasi Antisipatif Mahasiswa
PPA dan Non-PPA Pada Hubungannya Dengan Whistleblowing (Studi Kasus pada Mahasiswa Akuntansi Universitas Diponegoro)". Skripsi. Fakultas Ekonomika dan Bisnis, Universitas Diponegoro. Semarang.

(16) Sagara, Yusra. 2013. Profesionalisme Internal Auditor dan Intensi Melakukan Whistleblowing. Jurnal Liquidity. Vol. 2 No. 1. 34-44.

(17) Semendawai, Abdul Haris, dkk. 2011. Memahami Whistleblower. Jakarta: Lembaga Perlindungan Saksi dan Korban (LPSK)

(18) Soekanto, Soerjono. 2012. Sosiologi Suatu Pengantar. Jakarta: Rajawali Pers.

(19) Sugiyono. 2009. Metode Penelitian Bisnis (Pendekatan Kuantitatif, Kualitatif, dan $R \& D)$. Bandung: Alfabeta. 